\title{
Teaching Culture in EFL: Implications, Challenges and Strategies
}

\author{
Murshed Haider Choudhury \\ Faculty of Languages and Translation, King Khalid University, Saudi Arabia
}

\begin{abstract}
Language and culture have an inextricable and interdependent relationship. Learning a foreign language without learning the culture can only produce a "fluent fool," that is someone who speaks the language well but does not understand the social or philosophical context in which it exists. In this era of technology, globalization, immigration and mass media, it is even more imperative for EFL teachers to equip students with high level of intercultural communicative competence. This paper addresses some challenges faced by EFL teachers while teaching target culture and reinforces importance of incorporating culture in teaching English as Foreign Language and suggests how and which components of culture should be taught.

Keywords - culture, EFL, intercultural communication
\end{abstract}

\section{Introduction}

It has long been recognized by linguists and anthropologists that the forms and uses of a given language mirror the cultural values of the society in which the language is spoken. Teaching language in isolation cannot make a learner of the language competent in that language (Krasner, 1999). They need to be aware, for example, of the culturally appropriate ways to address people, express gratitude, make requests, and agree or disagree with someone. They should know that the behaviors and intonation patterns that are appropriate in their own speech community may be considered otherwise by members of the target language speech community. They have to realize that, in order for communication to be successful, language use must be in harmony with the culturally appropriate behavior. In this increasingly globalized and multicultural world, where English has got the status of the lingua franca or international language, EFL teachers cannot afford to ignore importance of teaching culture in developing what Byram (1997) calls 'intercultural communicative competence'.

Consequently, the question that comes up is which culture is the target culture in the EFL context: British or American? Thanks to British colonialism prior to mid-twentieth century and later emergence of the USA as the political, military and economic superpower, English has become the most widely spoken language in the world. However, it is no longer a universal and monolithic linguistic entity; the last century has witnessed proliferation of English to such an extent that there emerged the concept of World Englishes (Kachru, 1992), which consist of different varieties of English used in diverse sociolinguistic contexts. First, there is English from the USA, United Kingdom, and Australia, which Kachru (1992) placed in 'inner circle'; it represents the traditional historical and sociolinguistic bases of English where English is now used as the primary language. Then there are emerging localized or indigenized varieties developed in British colonized nations like India, Nigeria, Caribbean island nations, etc. which belong to the 'outer circle'. Finally, there is 'expanding circle', which includes China, Russia and Brazil.

This paper first defines what culture is in the EFL context. Then it will focus on why it's important to incorporate target culture in EFL classroom. There is a discussion on why making a bridge between the learners' own culture and the target culture is so important. The paper will also discuss challenges faced by language teachers while teaching target culture in more traditional societies as some reactionaries consider it a disguise for imposing cultural hegemony or linguistic imperialism. Finally, the paper recommends different strategies to make learning culture meaningful for students, so that they develop intercultural communicative competence.

\section{Definition Of Culture}

Culture is a highly complex and a broad concept to define. Kramsch (1998) describes culture as "membership in a discourse community that shares a common social space and history, and common imaginings" (p. 10). Liddicoat, Papademetre, Scarino and Kohler (2003) define culture as a complex system of concepts, attitudes, values, beliefs, conventions, behaviours, practices, rituals and lifestyles of the people who make up a cultural group, as well as the artifacts they produce and the institutions they create (p. 45). According to Hinkel (1999), it refers to areas of inquiry into human societies, groups, systems, behaviors, and activities. Brown (2000: 177) defines culture as "the ideas, customs, skills, arts and tools that characterize a given group of 
people in a given period of time"; while Brooks (1975: 20) refers to culture as "everything in human life and the best of everything in human life".

Lee and Peterson have categorized culture into two general types: Big " $\mathrm{C}$ " culture and little "c" culture (Lee 2009; Peterson, 2004). Lee (2009: 78) refers to Big "C" culture as "the culture which represents a set of facts and statistics relating to the arts, history, geography, business, education, festivals and customs of a target speech society." For Peterson (2004), the culture relating to grand themes, is classified under Big "C" culture which includes the following themes such as geography, architecture, classical music, literature, political issues, society's norms, legal foundation, core values, history, and cognitive processes.

The little "c" culture includes the routine aspects of life and encompasses everything as a total way of life. For Lee (2009: 78) this type of culture is "the invisible and deeper sense of a target culture" including attitudes or beliefs and assumptions. Peterson (2004) defines little "c" culture as the culture focusing on common or minor themes. It includes themes such as opinions, viewpoints, preferences or tastes, gestures, body posture, use of space, clothing styles, food, hobbies, popular music, and popular issues, and certain knowledge like, trivia, facts, etc.

\section{Relation Between Language And Culture}

Wei (2005:56) argues that language has a dual character: a means of communication as well as a carrier of culture. Language without culture is inconceivable, and vice versa. A particular language is a mirror of a particular culture. By studying a language, students gain knowledge and understanding of the culture in which the language is embedded; in fact, students cannot truly learn the language until they have also mastered the cultural contexts in which the language occurs. Fantini (1995) stressed the symbiotic relationship between language and culture since language affects and reflects culture and vice-versa. Brown (2000: 177) echoed the same when he says "a language is a part of a culture, and a culture is a part of a language; the two are intricately interwoven so that one cannot separate the two without losing the significance of either language or culture." In other words, language is regarded as a means by which people communicate to and interact with others, which in turn is responsible for cultural development.

Language and culture have an inextricable and interdependent relationship. Mitchell and Myles (2004) argue that "language and culture are not separate, but are acquired together, with each providing support for the development of the other" (p. 235). It is also shown in cultural denotations and connotations in semantics (Byram, 1989), cultural norms in communication (Kramsch, 1993) and the mediatory role of language in the social construction of culture (Kramsch, 1996). Liddicoat et al. (2003) also claim that language and culture interact with each other in a way that culture connects to all levels of language use and structures; i.e. there is no level of language which is independent of culture (Fig. 1). Moreover, the fact that language expresses, embodies and symbolizes cultural reality clearly shows that language and culture are bound together (Kramsch, 1998).

The relationship between language and culture is made meaningful in language learning as "the person who learns language without learning culture risks becoming a fluent fool" (Bennett, Bennett \& Allen, 2003, p. 237).

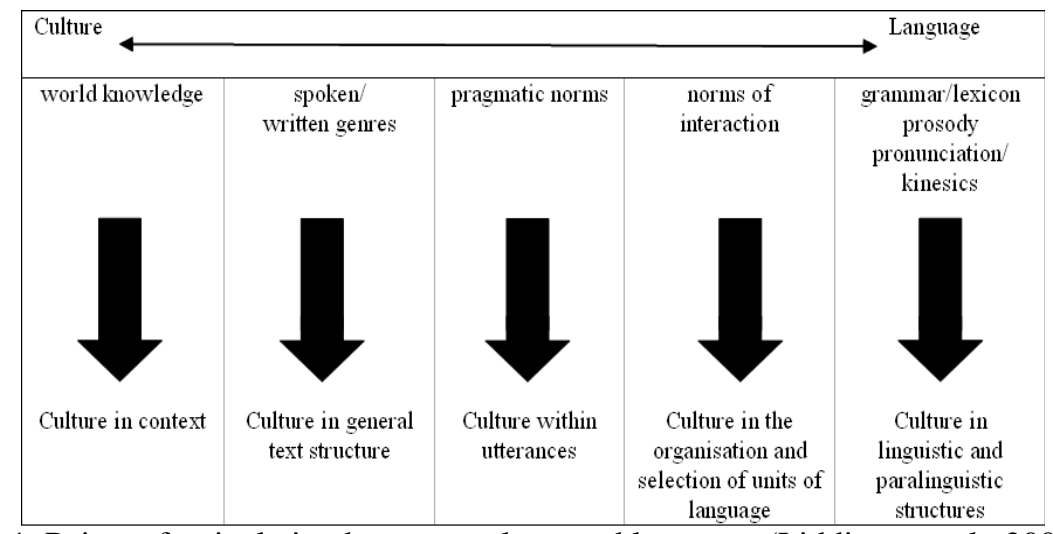

Figure 1. Points of articulation between culture and language (Liddicoat et al., 2003, p. 9)

Therefore, when it comes to the realm of teaching and learning, as Gao (2006) presents it, the interdependence of language learning and cultural learning is so evident that one can conclude that language learning is culture learning and consequently, language teaching is cultural teaching. Gao further states that foreign language teachers should be aware of the place of cultural studies in foreign language classroom and attempt to enhance students' cultural awareness and improve their communication competence. Wang (2008), likewise, asserts that "foreign language teaching is foreign culture teaching, and foreign language teachers are foreign culture teachers." 


\section{Importance of Culture in EFL}

In more traditional societies, EFL language teachers are hardly aware of the importance of cultural orientation. They consider communication as merely the application of grammatical rules in oral and written practice. In some cases, learning about the target culture is seen as a threat to the native values, and the importance of linguistically relevant information is neglected.

Since having a close contact with the target culture and its speakers is a rare opportunity for all language learners in countries from outer and expanding circles (Kachru, 1992), learners cannot appreciate the importance of learning the cultural aspects of communication unless they visit a foreign country and experience the difficulties. Nonverbal aspects of target culture are sometimes acquired from movies and TV serials, which are far from being helpful for communicative purposes or may sometimes develop misconceptions or stereotypes.

McKay (2003) claims that culture influences language teaching in two important ways: linguistically and pedagogically. Linguistically, culture is significant in the linguistic dimension of the language itself, affecting the semantic, pragmatic, and discourse levels of the language. Pedagogically, it influences the choice of language materials because cultural content of the language materials and the cultural basis of the teaching methodology are to be taken into consideration while deciding upon the language materials. He argues that in order to master a language students have to learn both, its linguistic and cultural norms.

Common European Framework claims cultural awareness and intercultural learning part of its policies in order to promote international understanding and world peace. Kitao (2000) also considers international understanding a benefit of culture learning and gives some other reasons why is it important to include culture in foreign language curriculum. Kitao claims that studying culture gives students a reason to study the target language because understanding culture makes studying foreign language and literature more meaningful.

Studying culture is also useful for teaching students to understand their own culture. Students' world view is determined by the values of their own culture. This can lead to problems when they are confronted with different cultures. Kitao (2000) claims that studying culture, besides already mentioned benefits, "gives students liking for the people of that culture", "helps avoid the stereotypes" and is part of general education.

After the communicative theories are introduced in the field of ELT, the integration of culture has started to gain even more importance. Trim (as cited in Starkey, 1999, p 53) explains communicative competence as "the ability to relativise learners' own cultural beliefs, values and practices, to understand those of others, to establish a relationship between the two, and to accept difference rather than expect some universal harmony". In this case, interaction with another culture makes it possible for language learners to relativise their own culture.

Tomalin (2008) is of the opinion that the international role of the English language and globalization are the two main reasons to teach culture as a 'fifth language skill', in addition to listening, speaking, reading and writing. "What the fifth language skill teaches you is the mindset and technique to adapt your use of English to learn about, understand and appreciate the values, ways of doing things and unique qualities of other cultures. It involves understanding how to use language to accept differences, to be flexible and tolerant of ways of doing things which might be different to yours. It is an attitudinal change that is expressed through the use of language."

One of the problems resulting from the use of the target culture in ELT is the fear that the students will be influenced by the target culture and lose their own identity since this may be categorized as linguistic imperialism. Some authors have suggested using both home language and target language culture to deal with the limitations of exclusively using one of the cultures. This idea is, according to Ariffin (2009), excellent because students are encouraged to discover similarities between their culture and the target language culture, which could bring about common understanding and tolerance.

The importance of incorporating culture in language teaching has been addressed by international and national foreign language associations, such as TESOL that has stipulated the 3rd goal in ESL Standards for Pre-K-12 Students "to use English in socially and culturally appropriate ways." American Council of teachers of Foreign Languages (ACTFL) also determines the standards based on "knowing how, when and why to say what to whom" (Onalan, 2005). In China's English Curriculum Standard, culture awareness is also one of the integrated language capabilities.

\section{Which Culture Is The Target Culture?}

When it comes to teaching English vis-à-vis culture, many teachers and learners are faced by an immediate choice: which culture to learn? The most popular choices, for historical and economic reasons, were British or American culture, with a mixture of small "c" and Big "C" cultures. Most international English Language Teaching materials also have an obvious bias towards British or American culture. The teachers and learners seem to be faced with a relatively easy choice. 
However, is it that easy? The more you unpack the notion of culture in teaching the more difficult it becomes. One problem is that there is no such thing as a monolithic national culture. People belong to any number of cultural groupings, for example: age, gender, regional origin, work, social class, religion and ethnic background. A failure to recognize this leads to the perpetuation of stereotypes.

Furthermore, it is true that English now occupies a unique position as a world language. English is no longer viewed as being the property of what Kachru (1992) calls the "Inner Circle" countries---Britain, the USA, Canada, Australia and New Zealand. This has led some to call for the teaching of English as an international language to be devoid of cultural content entirely, a 'neutral' or 'supranational' variety of English.

But others argue that even the emerging international variety of English is a North American sub-genre that threatens other languages and homogenizes culture. And yet, with culture featuring prominently in most school curricula as an integral part of the core English program, it can hardly be ignored.

There is another way of teaching culture which doesn't necessarily mean abandoning potentially motivating cultural material. It draws on the notion of intercultural competence (Byram, 1997). In simple terms, intercultural competence is the ability to communicate and operate effectively with people from another culture. More and more intercultural encounters are taking place these days for many different reasons:

- Technology (Internet, email, social media websites, chat, mobile phone technology) enables people to communicate faster, cheaper and further than before.

- Globalization brings people from different cultures into contact with each other more than in the past to do business.

- Increased movement of populations and immigration bring people from different cultures into contact with each other, sometimes causing tension and conflict.

- Modern warfare and media coverage (the 'War on Terror', the Iraq war) have the effect of simplifying and narrowing definitions of culture into good and bad, right and wrong.

The fact that English is the dominant international language means that English is being used more and more in the above interactions and that intercultural competence is needed to successfully negotiate them. Becoming inter-culturally competent involves recognizing differences and variations within one's own culture and within other cultures. It's about occupying what is called "a third place," a principled and detached view across cultures. It means abandoning the idea that everybody sees the world in pretty much the same way. What does this mean in practical terms for the English classroom? McKay (2002) argues that cultural material in class should be used to encourage students to reflect on their own culture and establish a "sphere of inter-culturality" (Kramsch 1993). In this sense, intercultural competence is not so much about knowledge as about skills. The skills that should be developed to enhance intercultural competence include:

- $\quad$ Asking questions.

- Listening and seeking clarification.

- $\quad$ Negotiating and identifying common ground.

- $\quad$ Avoiding prejudging or stereotyping.

\section{Conclusion}

Culture is therefore a crucial facet of teaching English as a Foreign Language. The goal behind teaching culture in EFL should be inculcating intercultural communicative competence among learners, rather than propagating or showing superiority of the target culture over native culture. The foreign culture should provide the mirror to the learners in which he can see his own culture reflected. It provides an outside to our inside. Culture learning should be a conscious, purposeful process in which the tacit is made explicit. Teaching culture is currently being understood as "aspect of values education" (Tomalin and Stempleski, 1993:4) based on critical thinking and developing tolerance towards differences. According to Byram (1997), culture learning is seen as a comparative process in which learners are encouraged to get aware of their own culture and contrast it with the target culture.

\section{Reference}

[1] I. Krasner, The role of culture in language teaching, Dialog on Language Instruction, 13(1-2), 1999, 79-88.

[2] M. Byram, Teaching and assessing intercultural communicative competence. (Clevedon: Multilingual Matters, 1997).

[3] B. Kachru, The other tongue: English across cultures (USA: University of Illinois Press, 1992).

[4] C. Kramsch, Language and culture (Oxford: Oxford University Press, 1998).

[5] A. J. Liddicoat, L. Papademetre, A. Scarino, and M. Kohler, Report on intercultural language learning (Canberra ACT: Commonwealth of Australia, 2003).

[6] E. Hinkel, Culture in second language teaching and learning (Cambridge: Cambridge University Press, 1999).

[7] H. H. Brown, Principles and language learning and teaching, 4th ed. (White Plains, NY: Addison Wesley Longman, 2000).

[8] N. Brooks, The analysis of foreign and familiar cultures, in R. Lafayette (Ed.), The culture revolution in foreign language teaching (Skokie, Illinois: National Textbook Company, 1975). 
[9] K-Y. Lee, Treating culture: What 11 high school EFL conversation textbooks in South Korea Do, English Teaching: Practice And Critique, 8, 2009, 76-96.

[10] B. Peterson, Cultural intelligence: A guide to working with people from other cultures, (Yarmouth, ME: Intercultural Press, 2004).

[11] Y. Wei, Integrating Chinese culture with TEFL in chinese classroom, Sino-US English Teaching, 2(7), 2005, 55-58.

[12] A. Fantini, Introduction-language, culture and world view: Exploring the nexus, International Journal of Intercultural Relations, 199(2), 1995, 143-153.

[13] R. Mitchell and F. Myles, Second language learning theories (2nd ed.) (London: Arnold, 2004).

[14] M. Byram, Cultural studies in foreign language education. (Philadelphia: Multilingual Matters, 1989).

[15] C. Kramsch, Context and culture in language teaching (Oxford: Oxford University Press, 1993).

[16] C. Kramsch, The cultural component of language teaching, Language, Culture and Curriculum, 8(12), 1996, 83-92. Retrieved May 15, 2008, from http://www.spz.tu-darmstadt.de/projekt_ejournal/jg_01_2/beitrag/kramsch2.htm.

[17] J. Bennett, M. Bennett, and W. Allen, Developing intercultural competence in the language classroom, in Culture as the core: Perspectives in second language learning (USA: Information Age Publishing, 2003).

[18] F. Gao, Language is culture: On intercultural communication, Journal of Language and Linguistics, 5(1), $2006,58-67$.

[19] X Wang, Reflection on the notion of culture teaching, US-China Foreign Language, 6(1), 2008, 49-53.

[20] S. L. McKay, The cultural basis of teaching English as an international language. TESOL Matters, 13 (4) $2003,1-6$.

[21] K. Kitao, Teaching Culture in Foreign Language Instruction in the United States, 2000 , Viewed 11 January 2005 at http://www1.doshisha.ac.jp/ kkitao/library/article/culture.htm.

[22] H. Starkey, Foreign language teaching to adults: Implicit and explicit political Education, Oxford Review of Education, 25 (1/2), $1999,53$.

[23] B. Tomalin, Culture: The fifth language skill, 2008, Viewed $11 \quad$ May $2013 \quad$ at http://www.teachingenglish.org.uk/think/articles/culture-fifth-language-skill.

[24] S. Ariffin, Culture in EFL teaching: Issues and solutions. 2009, Retrieved July 22nd, 2009 from http://web1.hpu.edu/images/Graduate Studies/TESL_WPS/10Ariffin_culture_a16631.pdf

[25] O. Onalan, EFL teachers' perceptions of the place of culture in ET: A survey study at four universities in Ankara, Turkey, Journal of Language and Linguistic Studies, 1(2), 2005.

[26] S. McKay, Teaching English as an International Language: Rethinking Goals and Approaches, (Oxford: Oxford University Press, 2002). 